\title{
Simulation and Organizational Studies in Japan
}

\author{
Nobuo TAKAHASHI ${ }^{\text {a) }}$
}

\begin{abstract}
Since the 1990s, simulation and organizational studies have been conducted in Japan. In this paper, we review the simulation and organizational studies in Japan, including the relationships between researchers. The global trend is to cite the results of simulation studies as metaphors. By contrast, in Japan, there are unique research groups which critically examine the existing models, perform simulations, and further test them against survey data. The lessons they learned are: (a) The animation of the simulation results stir the imagination of researchers and business persons. However, (b) if the phenomena indicated by simulation and the reality of parameter values are not supported by the survey data, the implications derived from simulation are no more than a delusion.
\end{abstract}

Keywords: computer simulation, garbage can model, evolution of cooperation, multi-agent simulation, exploration and exploitation

a) Graduate School of Economics, University of Tokyo, 7-3-1 Hongo, Bunkyo-ku, Tokyo, Japan, nobuta@e.u-tokyo.ac.jp

A version of this paper was presented at the ABAS Conference 2020 Winter (Takahashi, 2020).

(C) 2020 Nobuo Takahashi. This is an Open Access article distributed under the terms of the Creative Commons Attribution License, which permits unrestricted reuse, distribution, and reproduction in any medium, provided the original work is properly cited. 


\section{Introduction}

The development of the first all-purpose digital electronic computer, ENIAC began in 1943 during World War II with the goal of calculating the trajectory of new artilleries being developed and introduced one after another (Takahashi, 2011, 2013a, Chapter 5). The ENIAC was not completed in time for the end of the war, however before the completion ceremony in February 1946, the first calculation conducted to test ENIAC was for a plane wave in exploding a hydrogen bomb which was under development at the time at Los Alamos National Laboratory (Takahashi, 2011, 2013a, Chapter 6). In each case, all can be calculated with a computer instead of actually testing with shooting shells or exploding a hydrogen bomb, therefore a computer was originally created as a machine for simulation.

For management applications, the MIT group ran a simulation model incorporating a positive/negative feedback loop on a computer and called it Industrial Dynamics (Forrester, 1961). Around the same time, the Carnegie Institute of Technology (renamed Carnegie Mellon University in 1965) performed a similar simulation of corporate behavior (Cyert \& March, 1963). In both cases, corporate behavior was represented by a mathematical formula, which was calculated with time. As a result, simulation of corporate behavior was represented with a curve line or a polygonal line by plotting time on the horizonal axis and the focused variable on the vertical axis.

DYNAMO, the compiler dedicated to Industrial Dynamics, was used for urban problems, earth resources problems, etc., and it was called System Dynamics (SD). The results of SD analysis commissioned by the Club of Rome to the MIT project team were published as The limits to growth (Meadows, Meadows, Randers, \& Behrens, 1972) which attracted worldwide attention. However, the causal relationship of the world model (e.g., Meadows et al., 1972, pp. 102-103, Figure 26) was too complicated, serving as no more 
than a blackbox.

After all, SD had hardly penetrated until the end of the 1980s in Japan (Miyakawa \& Kobayashi, 1988), as in the simulations of Cyert and March (1963). ${ }^{1}$ However, simulation and organizational studies began in the 1990s in Japan. Inamizu (2013) reviewed the simulation studies conducted in the United States including the relationships between researchers. In this paper, we review the simulation studies in Japan using the same method. Unlike the global trend, which cites only the results of simulation studies as metaphor, there are unique research groups in Japan which critically examine the existing models, perform simulations, and further test them against survey data.

\section{Garbage Can Model}

The garbage can model of Cohen, March, and Olsen (1972), published in the same year as The limits to growth, suggested the existence of a seemingly insane but interesting phenomenon "decision making by flight" in simulation. Does it really exist? The author surveyed approximately 8,500 white-collar workers in a total of 40 Japanese companies every year for 10 years starting from 1991 (Takahashi, 1992) until 2000. As a result, it was found that $53 \%$ of the workers experienced the phenomenon (Takahashi, 2015, Chapter 4). However, in fact, studies that confirm such results of the garbage can model were rare worldwide.

On the contrary, few subsequent studies have actually tried simulation, although Cohen et al. (1972) were accompanied with a simulation program. Guido Fioretti has collected and published garbage can model programs on his website, ${ }^{2}$ however there are only

1 Recently, Cyert, and March (1963) have been re-evaluated (Gavetti, Levinthal, \& Ocasio, 2007).

2 http://www.cs.unibo.it/fioretti/CODE/GC/index.html 
eight programs in total. The author's Single Garbage Can Model (Takahashi, 1997a) is also included, however Takahashi (1997a) follows Cohen et al. (1972) in chronological order, which was 25 years later.

No one pointed it out because no one seriously tried it again, ${ }^{3}$ however the program of Cohen et al. (1972) was flawed. Actually, Inamizu (2015) clearly indicates the following three points: (1) their program failed to detect the three decision making styles (decision making by resolution/by oversight/by flight); (2) decision making sometimes occurred not only when choice opportunities had no problems but also when a choice opportunity had no decision maker; and (3) even when there were no problems attached to choice opportunities, the initial setting was programmed as though there were, perhaps to avoid the decision making seen in (2). In other words, the garbage can model has never been properly considered and has only been referred to as a metaphor (e.g., Lynn, 1982).

\section{The Parameter to Evolve Cooperation}

The most influential simulation study in political science is Robert Axelrod's The evolution of cooperation (Axelrod, 1984). He conducted two types of simulation described below based on a novel idea in which the programs play the repeated game of the prisoner's dilemma.

A) He conducted the first round of the tournament, in other words, a round-robin league match between computer programs of 14 professional game theorists (Axelrod, 1980a). On the basis of the feedback on an analysis of the first round results, he conducted the second round of the tournament that was based on the

3 Inamizu (2010, 2014a) retested in FORTRAN, Excel, artisoc, which was exceptional. 
programs of 62 players, including players from the first round (Axelrod, 1980b). ${ }^{4}$

B) Then, he conducted a simulation of the evolution of 1000 generations by the rule that the share of a given program in a round $i+1$ will be proportional to the program's tournament score in the previous round $i$ based on the result of the second round of the tournament (Axelrod, 1980b).

The results were compiled in Axelrod (1984) with an appealing message that humans will cooperate even if they are free as long as the future parameter defined as the probability of playing the next move (Takahashi, 2013c) is sufficiently high. It turned the Hobbes-like view of the world of "the war of all against all" upside down.

Below is a narrative approach describing how simulation has been received and developed among researchers in Japan mainly based on the author's experience. In 1991, Tetsuo Kondo and the author returned to the University of Tokyo as associate professors. Kondo received his Ph.D. from the University of Chicago and published Kondo (1990). It was him who introduced us to Axelrod's research. Kondo was making students write programs in undergraduate courses, and practiced computer tournaments in Axelrod's type A). However, he died suddenly in 1994 at the age of 34. Takashi Shimizu (currently a professor at the University of Tokyo) took one of Kondo's classes, and then entered my undergraduate seminar course in 1994 at the recommendation of Kondo. Shimizu published Shimizu (1997), which developed the simulation of type B) during master's program, and also wrote a paper in honor of Kondo which was published in Takahashi (1996b).

4 Because each has the program "RANDOM", which selects "cooperation" and "defection" randomly with the same probability, the number of programs to compete against is 15 for the first round and 63 for the second round. 
In the short time when the author was a colleague of Kondo, the bubble burst in the Japanese economy after land prices peaked between 1991 and 1992 (Takahashi, 2017). In that period of economic stagnation, the author developed a perspective index in 1992 and started measurement. The finding was that the perspective index was surprisingly powerful in explaining the job satisfaction ratio, turnover candidate ratio and other variables. At that time, after hearing about Kondo's research, the thought came that the perspective index was a type of future parameter (Takahashi, 1996a, 1997b, 2013c). Since then, the perspective index survey was conducted continuously, its character was confirmed as a future parameter (Takahashi, 1998a, 2014, 2018a, 2018b, 2019; Takahashi, Ohkawa, \& Inamizu, 2009, 2014a; Takahashi, Ohkawa, Inamizu, \& Akiike, 2013).

\section{Simulation Videos Spark Your Imagination}

Before his death, Kondo introduced the author to his undergraduate and graduate senior Shota Hattori. Kozo Keikaku Engineering Inc. (KKE), led by Hattori, would become a big promoter to spread multi-agent simulation, also known as agent-based simulation, in Japan. Multi-agent simulation attracted attention in the 1990s complexity boom (e.g., Epstein \& Axtell, 1996). In this complexity boom, Axelrod (1997) and Axelrod and Cohen ${ }^{5}$ (1999) even called themselves complexity.

In the multi-agent simulation, multiple agents behave in the space on the computer based on each rule. Even if each agent's rule itself is simple, the sum total of the behaviors of individual agents will result in complex movements that could not be predicted.

General-purpose calculation software such as Mathematica or a

5 An author of Cohen et al. (1972). 
dedicated simulator such as Swarm of the Santa Fe Institute is used for multi-agent simulation. KKE developed a dedicated simulator. The prototype was called KK-MAS and was released in the spring of 2006 as artisoc (compound term formed from artificial societies). In the process, a number of researchers became lead users of artisoc. Prof. Susumu Yamakage's group of the University of Tokyo was the center of the lead users, and his group's efforts produced results in a series of studies (e.g., Yamakage \& Hattori, 2002) and textbook (Yamakage, 2007). ${ }^{6}$

Being one of the lead users, in July 1999, the author attended the 4th Annual Colloquium on the Application of Complex Adaptive Systems to Business; "Embracing Complexity" held at the Cambridge Center Marriott in front of MIT with research associate Kenichi Kuwashima (currently an associate professor at the University of Tokyo) specializing in pharmaceutical $\mathrm{R} \& \mathrm{D}$ on the recommendation of Hattori. As a sideline to the meeting, we visited the research institute and headquarters of Merck \& Co. (the world's number one pharmaceutical company based on sales at that time) on the recommendation of Banyu Pharmaceutical Co., a subsidiary of Merck (acquired in 1984). We were inspired by Merck's amount of ideas in R $\&$ D, Duncan Watts' path length (Watts \& Widdowson, 1999, 2000), and then designed a simulation model called "communication competition model."

Consequently, we wrote a Discussion Paper (Takahashi, Kuwashima, \& Tamada, 2000) which was later published in

6 artisoc can also be used for various models in management. For example, Hideki Fujita (currently an associate professor at Toyo University), who was a classmate of Shimizu at seminars the author held at the University of Tokyo, conducts simulation of achievement motivation (Fujita, 2000, 2009). At the Manufacturing Management Research Center (MMRC), the University of Tokyo, Takahashi, Ohkawa, Hatta, Inamizu, and Ogami (2009) conducted simulation of acculturation, and Iwao (2019) conducted simulation of Kaizen. 
Kuwashima, Takahashi, and Tamada (2004, 2005), and presented a paper "Communication competition model" (Kuwashima, Takahashi, $\&$ Tamada, 2000) at the 28th annual meeting of the Behaviormetric Society, University of Tokyo in October 2000. However, there was no response from the floor. At the colloquium, a senior researcher on the floor asked a young presenter about the difference from SD, in fact, the graph used in the presentation, like SD, showed a curve line or polygonal line with time on the horizontal axis and focused variables on the vertical axis.

Almost a week later, we made a presentation with the same title at the KKE Customers Conference 2000 (Takahashi \& Kuwashima, 2000). This time, we cut off the presentation early, and showed the animation of the multi-agent simulation using the projector during half of the time. Then, researchers from the floor raised hands one after another and asked questions, which was completely different from the time of the annual meeting. We recognized that even an such simple animation which “॰” moves around has the power to evoke people's imagination.

In 2001, one undergraduate student came to my seminar course after reading our Discussion Paper (Takahashi et al., 2000) and said he wanted to do simulation. His name was Nobuyuki Inamizu (currently an associate professor at the University of Tokyo). He frequently visited the Yamakage lab and became a co-author of Chapter 2 of Yamakage and Hattori (2002) during his undergraduate years.

One of studies by Inamizu, who went to graduate school, was to reproduce a garbage can model as a multi-agent simulation (Inamizu, 2006). When the author had the chance to give a speech at the breakfast meeting of Company $\mathrm{N}$ executives in May 2004, the $\mathrm{U}$ Managing Director invited me to visit the office after the lecture and said "It's interesting. It is a non-territorial office." Having accepted this invitation, while listening to the explanation of the $\mathrm{U}$ Managing 
Director and the people there, the thought that it was an office that was just like a drawing of the garbage can model came to mind. After a while the author visited the office again this time with Inamizu, taking a laptop computer and showed U Managing Director an animation of a multi-agent simulation of the garbage can model. $U$ Managing Director exclaimed, "This is it!" The power of the multi-agent simulation's animation is amazing because he immediately promised to cooperate with Inamizu's on-site survey. This survey of Company $\mathrm{N}$ triggered Inamizu's research on office density of non-territorial office, and then he wrote his doctoral dissertation and published Inamizu (2014a, 2014b).

\section{Self-enforced Equilibrium is a World of Death}

In addition, the animation reminded us of something unexpected. When we saw the results of simulation of trial "communication competition model" that was first built, we noticed something strange. The model was designed (called "rational model") so that "an agent moves to the position that has the highest amount of effective ideas among the movable positions including the current position. Therefore, when the performance is degraded when the agent moves from the current position, a phenomenon in which the agent stays at the current position occurs. That is self-enforcing “equilibrium." However, as we've seen, all agents run forever and are not in equilibrium.

The trial program was actually wrong. "The agent moves to the position with the highest amount of effective ideas among the movable positions other than the current position." In other words, as long as there is a place where an agent can move, it always moves (this was called "wandering model"). This cannot be in equilibrium forever. The shape of the cluster itself was constantly changing as if amoeba was stretching the feeler and gathering the agents around 
(This animation attracted people's attention at the KKE's Customers Conference in 2000).

Therefore, when we switched the program to the "right" rational model, the screen stopped right away. It was not a bug. It becomes self-enforcing and falls into equilibrium in a very short time. The still screen was like a dead world. An equilibrium is a dead world which is in contrast to the amoeba animation of a wandering model. In addition, the rational model surprisingly had significantly lower long-term performance (Takahashi, Kuwashima, \& Tamada, 2006). In theory, the wandering model should have clearly lower performance in the short term than the rational model. This is because even if the amount of effective ideas at the current position were highest, the agent will abandon the current position and will move to another position. However, the rational model had significantly lower long-term performance than the wandering model. Then, it may be doubtful that equilibrium is the desired state, as economists believe. The wandering model which is not in equilibrium forever may be better.

The property of the wandering model which "moves to a movable position other than the current position" is consistent with the concept of "propensity to change." This concept was originally used in Effective Temperature Hypothesis proposed by Takahashi (1989) to explain the lukewarm feeling of Japanese companies. The propensity to change is defined as the propensity neither to accept the present situation nor to spend an easygoing time and to challenge the status quo (Takahashi, 2013b). Effective Temperature Hypothesis means that lukewarm feeling can be explained by a difference between the body temperature, propensity to change of an organization member, and system temperature, propensity to change as the system. Effective Temperature Hypothesis is supported by data based on tens of thousands of people (Takahashi, 1993, 1997b, 2013b; Takahashi, Ohkawa, \& Inamizu, 2009, 2014b). There is a 
phenomenon that dare to challenge rather than equilibrium leads to higher performance in the long term, and propensity to change can be measured.

\section{Realistic Value of Parameter?}

In 1989, a conference on organizational learning was held at Carnegie Mellon University to commemorate James March. There are 10 papers published in the special issue on organizational learning of Organization Science (Vol. 2, No. 1, 1991) followed by four papers in a later issue (Vol. 3, No. 1, 1992). Cohen and Sproull (1996) was published, adding nine papers to these 14 papers. Among them, March (1991) contrasts exploration with exploitation, and also became famous when Levinthal and March (1993) later called myopia of learning a phenomenon in which exploitation was prioritized over exploration. March (1991), which lists the exploration and exploitation of the current trend (O'Reilly \& Tushman, 2016) in the title of the paper, was actually a paper that developed and analyzed two simulation models.

However, both simulations had problems in the domain settings. For example, in the latter half, that is the competitive ecology model, the three lines of March (1991), Figure 6 with $N=2, N$ $=10$, and $N=100$ clearly cross the vertical axis at about 0.2 , about 0.8 , and about 1.7 , respectively. However, in practice, these lines can be obtained analytically in mathematics without performing simulation, and in fact, these were tangent parabolas that touch the vertical axis at $0.44,1.34$, and 2.33 respectively (Takahashi, 1998b, Figure 6).

The first half, the mutual learning model, is also suspicious (Takahashi, 1998b). Figure 1 of March (1991) looks like a graph of a monotonically decreasing function, but in fact its curve starts from the socialization rate $p_{1}=0.1$, and the curve to the left is missing. If 
the missing part is supplemented, as shown in Figure 3 of Mitomi and Takahashi (2015), there is actually a peak in the missing part where the socialization rate $p_{1}$ is almost 0.06 to 0.07 . "Slower socialization (lower $p_{1}$ ) leads to greater knowledge at equilibrium than does faster socialization" (March, 1991, p. 75) is clearly a mistake. The conclusion that "slow learning on the part of individuals maintains diversity longer, thereby providing the exploration that allows the knowledge found in the organizational code to improve" (March, 1991, p. 76) cannot be arrived at using this model. Actually, there is an optimal socialization rate that maximizes the average knowledge level (Mitomi \& Takahashi, 2015, pp. 45-46).

The biggest problem is whether the socialization rate 0.06 to 0.07 in the simulation model can be a low value that can never occur or whether the socialization rate is a common value. If the values of the parameters set in the simulation model are not supported by the survey data as being realistic, the predictions derived therefrom are merely delusions that never occur. In other words, it is impossible to argue with simulation alone.

\section{Although the Computer Has Advanced}

The history of simulation is closely related to the performance improvement of computers. SD was a product of the era of the mainframe computer. The program of the garbage can model in Cohen et al. (1972) was written in FORTRAN, which was also a standard high-level programming language used in mainframes. At that time, in order to save computer resources to share, a program written in high-level programming language (source code in a modern sense) was translated into machine language at once with a compiler, transformed into a load module (a binary code in the modern sense) and reused it. The first compiler was developed for FORTRAN in 1957. That is why the compiler for SD was called DYNAMO. However, 
when the processing speed has improved, the interpreter that executes the source code while interpreting it sequentially was no longer a practical problem, and the presence of the compiler diminished.

Mainframes were only available at universities and large corporations. Moreover, in order to use them at universities, the budget for computer use was first required to be obtained. The budget was limited and, for example, the author was working as a computer instructor to get a separate budget for the part-time job even after becoming a research associate. Those who can run a large program were limited to some privileged researchers.

In the 1980s, PCs began to become popular, and researchers at universities were finally released from mainframe computer budget constraints. Afterwards, BASIC, which is a simplified version of FORTRAN, was established as a high-level programming language for PCs. BASIC was an interpreter, not a compiler. Axelrod (1984)'s computer tournament was in transition, and the programs were written in FORTRAN or BASIC (Axelrod, 1984, p. 43). Takahashi (1997a) calculated on a PC, so the Single Garbage Can Model was written in BASIC.

In the late 1990s, the performance of PCs improved and simulation became possible with spreadsheets. Shimizu (1997) simulated using Excel. Kuwashima and Takahashi (2001, Chapter 3) rewrote the Single Garbage Can Model with Excel, and Inamizu (2015) created and published a garbage can model using Excel. However, at that time PCs still had limitations on calculation speed. Therefore, it took too much time to calculate KK-MAS program in the "Communication competition model" on a PC, and it was unavoidable that coauthor KKE's Masaki Tamada calculated it during the night on KKE's server.

In Japan, due to the improvement of computer performance, additional tests and retests of old models that were once strictly executed in terms of performance have been performed. However, 
there were few such research done in places other than Japan. This was a major problem. In other words, it was the source of uniqueness on the part of researchers that, on a global or journal basis, they could only be run with state-of-the-art computers. When the performance of a computer improves and anyone can simulate, its uniqueness is lost. Model and simulation experts pursued another uniqueness: create complicated models that can be understood only by peers, and with self-praise or by strictly imposing standards and methodologies (Davis, Eisenhardt, \& Bingham, 2007; Harrison, Lin, Carroll, \& Carley, 2007), trying to academically eliminate interesting simulations of half amateurs. This cycle has repeatedly led to a number of declines in simulation research.

\section{Conclusion}

To describe in a rather extreme manner, if the formula of a program has a systemic meaning, the calculation is simulation. If you perform simulation, you can make rough predictions even for problems that are difficult to handle analytically in mathematics or problems that you do not intuitively imagine. However, simulation must not be formed as an academic form by itself. Just as computing is no longer the monopoly of some researchers, simulation must not be proprietary to some researchers:

(a) because simulation exists in order for the model to breathe in the real world. Simulation is used to visualize and animate so that humans in the real world (including non-professional amateurs) can check it and to stir their imagination; and

(b) because the model cannot claim validity by simulation itself. If simulation suggests phenomena outside the common sense or unknown important parameters, it is necessary to research whether it actually exists and can be measured and confirm it 
with actual data. And if the phenomenon exists, or if the phenomenon can be explained by the difference in parameters, it will be the evidence of the validity of the model.

Simulate (reproduce) inspiration obtained from the real world by using a model and confirm the result in the real world. The potential and future of organizational simulation is in the hands of great amateurs who do not surrender to the threat of simulation experts.

\section{Acknowledgments}

This work was supported by JSPS KAKENHI Grant Number JP19K01857 for FY 2019-2023 and JSPS Grant-in-Aid for Publication of Scientific Research Results, Grant Number JP16HP2004.

\section{References}

Axelrod, R. (1980a). Effective choice in the prisoner's dilemma. Journal of Conflict Resolution, 24(1), 3-25.

Axelrod, R. (1980b). More effective choice in the prisoner's dilemma. Journal of Conflict Resolution, 24(3), 379-403.

Axelrod, R. (1984). The evolution of cooperation. New York, NY: Basic Books.

Axelrod, R. (1997). The complexity of cooperation: Agent-based models of competition and collaboration. Princeton, NJ: Princeton University Press.

Axelrod, R., \& Cohen, M. D. (1999). Harnessing complexity: Organizational implications of a scientific frontier. New York, NY: Free Press.

Cohen, M. D., March, J. G., \& Olsen, J. P. (1972). A garbage can model of organizational choice. Administrative Science Quarterly, 17(1), 1-25.

Cohen, M. D., \& Sproull L. S. (Eds.) (1996). Organizational learning. Thousand Oaks, CA: Sage.

Cyert, R. M., \& March, J. G. (Eds.) (1963; 1992). A behavioral theory of the firm. Englewood Cliffs, NJ: Prentice-Hall. 2nd ed. Cambridge, MA: 
Blackwell.

Davis, J. P., Eisenhardt, K. M., \& Bingham, C. B. (2007). Developing theory through simulation methods. Academy of Management Review, 32(2), 480-499.

Epstein, J. M., \& Axtell, R. (1996). Growing artificial societies: Social science from the bottom up. Washington, DC: Brookings Institution Press.

Forrester, J. W. (1961). Industrial dynamics. Cambridge, MA: M.I.T. Press. Fujita, H. (2000). Tassei dōkidzuke to hokori [Achievement motivation and pride] Proceedings of the 28th Annual Meeting of the Behaviormetric Society of Japan, 337-338 (in Japanese).

Fujita, H. (2009). Koa tekisuto mikuro soshiki-ron [Core textbook micro-organization theory]. Tokyo, Japan: Shinsei Sha (in Japanese).

Gavetti, G., Levinthal, D., \& Ocasio, W. (2007). Perspective-Neo-Carnegie: The Carnegie School's past, present, and reconstructing for the future. Organization Science, 18(3), 523-536.

Harrison, J. R., Lin, Z., Carroll, G. R., \& Carley, K. M. (2007). Simulation modeling in organizational and management research. Academy of Management Review, 32(4), 1229-1245.

Inamizu, N. (2006). Maruchiējentoshimyurēta o tsukatta gomibako moderu no saikentō [Re-examination of "garbage can model" using multi agent simulator] Kodo Keiryogaku [The Japanese Journal of Behaviormetrics], 33(2), 141-157 (in Japanese). doi: $10.2333 / \mathrm{jbhmk} .33 .141$

Inamizu, N. (2010). Mi bunkana soshiki kōzō to mondaikaiketsu ishi kettei: Gomibako moderu no shimyurēshon bunseki [Problem-solving and decision-making in unsegmented organization structure: An analysis of garbage can simulation model]. Soshiki Kagaku [Organizational Science], 43(3), 72-85 (in Japanese).

Inamizu, N. (2013). Keiei soshiki no konpyūtā shimyurēshon: J. G. March-kei soshiki riron no hatten no keifu [Computer simulation of business organization: A history of the development of J. G. March organizational theory]. In the Academic Association for Organizational Science (Ed.), Soshiki-ron rebyū II: Gaibu kankyō to keiei soshiki [Organization theory review II: External environment and 
organizations] (pp. 179-226). Tokyo, Japan: Hakuto Shobo.

Inamizu, N. (2014a). Ryūdō-ka suru soshiki no ishi kettei: Ējento bēsu apurōchi [Communication and decision-making in a fluid organization: Agent-based approach]. Tokyo, Japan: University of Tokyo Press (in Japanese).

Inamizu, N. (2014b). Two densities for successful non-territorial offices: A case of Microsoft Japan. Annals of Business Administrative Science, 13, 105-127. doi: 10.7880/abas. 13.105

Inamizu, N. (2015). Garbage can code: Mysteries in the original simulation model. Annals of Business Administrative Science, 14, 15-34. doi: $10.7880 /$ abas. 14.15

Iwao, S. (2019). Inobēshon o umu kaizen: Jidōsha kōjō no kaizen katsudō to zensha no soshiki sekkei [The Kaizen activities revisited: Organizational structures and innovation strategies in the Japanese auto industry]. Tokyo, Japan: Yuhikaku (in Japanese).

Kondo, T. (1990). Some notes on rational behavior, normative behavior, moral behavior, and cooperation. Journal of Conflict Resolution, 34(3), 495-530.

Kuwashima, K., \& Takahashi, N. (2001). Soshiki to ishi kettei [Organizations and decisions]. Tokyo, Japan: Asakura Shoten (in Japanese).

Kuwashima, K., Takahashi, N., \& Tamada, M. (2000). Komyunikēshon kyōsō moderu: ABS ni yoru soshiki keisei mekanizumu bunseki [Communication competition model: ABS analysis of organization formation mechanism]. Proceedings of the 28th Annual Meeting of the Behaviormetric Society of Japan, 339-342 (in Japanese).

Kuwashima, K., Takahashi, N., \& Tamada, M. (2004). Kenkyū kaihatsu pafōmansu to komyunikēshon: Maruchiējento shimyurēshon to jirei bunseki o tōshite [R\&D performance and communication: Multi-agent simulation and case study]. Kenkyū Gijutsu Keikaku [Journal of Science Policy and Research Management], 19(3/4), 214-225 (in Japanese). doi: 10.20801/jsrpim.19.3_4_214

Kuwashima, K., Takahashi, N., \& Tamada, M. (2005). An analysis of organizing process of R\&D projects: Multi-agent simulation and case study. Annals of Business Administrative Science, 4, 9-20. doi: 
10.7880/abas. 4.9

Levinthal, D. A., \& March, J. G. (1993). The myopia of learning. Strategic Management Journal, 14(S2), 95-112.

Lynn, L. H. (1982). How Japan innovates: A comparison with the U.S. in the case of oxygen steelmaking. Boulder, CO: Westview Press.

March, J. G. (1991). Exploration and exploitation in organizational learning. Organization Science, 2(1), 71-87.

Meadows, D. H., Meadows, D. L., Randers, J., \& Behrens, W. W., III (1972). The limits to growth: A report for the Club of Rome's project on the predicament of mankind. New York, NY: Universe Books.

Mitomi, Y., \& Takahashi, N. (2015). A missing piece of mutual learning model of March (1991). Annals of Business Administrative Science, 14, 35-51. doi: 10.7880/abas. 14.35

Miyakawa, T., \& Kobayashi, H. (1988). Shisutemu dainamikkusu: Keiei keizai-kei no dōgaku bunseki [System Dynamics: Dynamic analysis of management and economics]. Tokyo, Japan: Hakuto Shobo (in Japanese).

O'Reilly, C. A., III, \& Tushman, M. L. (2016). Lead and disrupt: How to solve the innovator's dilemma. Stanford, CA: Stanford Business Books.

Shimizu, T. (1997). Yūgen hanpuku shūjin'nojirenma ni okeru kyōchō kōdō no shinka [Evolution of cooperation in the finitely repeated prisoner's dilemma]. Kodo Keiryogaku [The Japanese Journal of Behaviormetrics], 24(1), 101-111 (in Japanese). doi: $10.2333 / \mathrm{jbhmk} .24 .101$

Takahashi, N. (1989). Nihon kigyō no nurumayu-teki taishitsu [A lukewarm constitution of Japanese firms]. Kodo Keiryogaku [The Japanese Journal of Behaviormetrics], 16(2), 1-12 (in Japanese). doi: $10.2333 / \mathrm{jbhmk} .16 .2 \_1$

Takahashi, N. (1992). Nihon kigyō ni okeru yarisugoshi [Decision making by flight in Japanese firms]. Soshiki Kagaku [Organizational Science], 26(3), 21-32 (in Japanese).

Takahashi, N. (1993). Nurumayu-teki keiei no kenkyu [A study of lukewarm management]. Tokyo, Japan: Toyo Keizai Shinposha (in Japanese). doi: 10.15083/00074362

Takahashi, N. (1996a). Mitōshi to soshiki kinkō [Perspective and 
organizational equilibrium]. Soshiki Kagaku [Organizational Science], 29(3), 57-68 (in Japanese).

Takahashi, N. (Ed.) (1996b). Mirai keisha genri: Kyōchō-tekina keiei kōdō no shinka [Leaning on future principle: Evolution of cooperative administrative behavior]. Tokyo, Japan: Hakuto Shobo (in Japanese).

Takahashi, N. (1997a). A single garbage can model and the degree of anarchy in Japanese firms. Human Relations, 50(1), 91-108. doi: 10.1023/a:1016957500937

Takahashi, N. (1997b). Nihon kigyō no ishi kettei genri [Principles of decision-making in Japanese firms]. Tokyo, Japan: University of Tokyo Press (in Japanese). doi: 10.15083/00074167

Takahashi, N. (1998a). Ishi kettei genri to Nihon kigyō [Decision-making principles and Japanese firms]. Soshiki Kagaku [Organizational Science], 31(4), 14-27.

Takahashi, N. (1998b). Soshiki rūchin to soshiki-nai ekorojī [Organizational routines and intraorganizational ecology]. Soshiki Kagaku [Organizational Science], 32(2), 54-77.

Takahashi, N. (2011). Kara: (4) Sekai-hatsu no han'yō dejitaru denshi keisanki Eniakku [Shell: (4) The first all-purpose digital electronic computer ENIAC]. Akamon Management Review, 10(8), 557-584 (in Japanese). doi: 10.14955/amr.100801

Takahashi, N. (2013a) Kara [Shell]. Kyoto, Japan: Minerva Shobo (in Japanese).

Takahashi, N. (2013b). A hypothesis about lukewarm feeling in Japanese firms. Annals of Business Administrative Science, 12, 237-250. doi: 10.7880 /abas. 12.237

Takahashi, N. (2013c). On the future parameter. Annals of Business Administrative Science, 12, 277-290. doi: 10.7880/abas.12.277

Takahashi, N. (2014). Future parameter explains job satisfaction and turnover candidates in Japanese companies. Annals of Business Administrative Science, 13, 129-140. doi: 10.7880/abas.13.129

Takahashi, N. (2015). Keiei-gaku de kangaeru [Management think]. Tokyo, Japan: Yuhikaku (in Japanese).

Takahashi, N. (2017). Checking firms' life spans expected 30 years ago. Annals of Business Administrative Science, 16, 257-263. doi: 
10.7880/abas.0170919a

Takahashi, N. (2018a). Talks with the president raise future expectations. Annals of Business Administrative Science, 17, 109-121. doi: 10.7880/abas.0180506a

Takahashi, N. (2018b). Fresh/long-time employees have better perspective but what of the others? Annals of Business Administrative Science, 17, 263-273. doi: 10.7880/abas.0181119a

Takahashi, N. (2019). Mitōshi shisū no chōki-teki teiten kansoku [Long-term fixed-point observations of perspective index]. Transactions of the Academic Association for Organizational Science, 8(2), 7-13 (in Japanese). doi: 10.11207/taaos.8.2_7

Takahashi, N. (2020, February). Simulation and organization studies in Japan. Paper presented at ABAS Conference 2020 Winter, University of Tokyo, Japan.

Takahashi, N., \& Kuwashima, K. (2000, October). Komyunikēshon kyōsō moderu [Communication competition models]. Customers Conference 2000 of Kozo Keikaku Engineering, Tokyo, Japan (in Japanese). Transcript retrieved from http://www2.kke.co.jp/event/cc2000/takahashi.html

Takahashi, N., Kuwashima, K., \& Tamada, M. (2000). Komyunikēshon kyōsō moderu to gētokīpā: Ėjento bēsudo shimyurēshon to Meruku-sha no jirei [Communication competition models and gatekeepers: Agent-based simulation and the case of Merk]. (Discussion Paper Series CIRJE-J-33). Center for International Research on the Japanese Economy, Faculty of Economics, University of Tokyo (in Japanese). Retrieved from http://www.cirje.e.u-tokyo.ac.jp/research/dp/2000/2000cj33.pdf

Takahashi, N., Kuwashima, K., \& Tamada, M. (2006). Komyunikēshon kyōsō moderu to gōri-sei [Communication competition model and rationality]. Journal of Economics, 72(3), 2-20. Society of Economics, University of Tokyo (in Japanese).

Takahashi, N., Ohkawa, H., Hatta, M., Inamizu, N., \& Ogami, M. (2009). Gijutsu shinka to komyuniti no bunka hen'yō moderu [The technological evolution and the acculturation model of communities]. Journal of Economics, 75(3), 63-78. Society of 
Economics, University of Tokyo (in Japanese).

Takahashi, N., Ohkawa, H., \& Inamizu, N. (2009). Soshiki no kōnaringu: Oractika ni yoru tsuishi to torēsu [Organizational cornering: Follow-up and tracing with oractika]. Akamon Management Review, 8(8), 433-462 (in Japanese). doi: 10.14955/amr.080801

Takahashi, N., Ohkawa, H., \& Inamizu, N. (2014a). Perspective index in Company X from 2004-2013. Annals of Business Administrative Science, 13, 231-242. doi: 10.7880/abas.13.231

Takahashi, N., Ohkawa, H., \& Inamizu, N. (2014b). Lukewarm feeling in Company X from 2004-2013. Annals of Business Administrative Science, 13, 343-352. doi: 10.7880/abas.13.343

Takahashi, N., Ohkawa, H., Inamizu, N., \& Akiike, A. (2013). Soshiki no dashin chousahou [Percussive methods of organization studies]. Soshiki Kagaku [Organizational Science], 47(2), 4-14 (in Japanese). doi: 10.11207/soshikikagaku.47.2_4

Watts, D., \& Widdowson, B. (1999, July). Beyond hierarchies: Networks \& organizational performance. The 4th Annual Colloquium on the Application of Complex Adaptive Systems to Business, Cambridge, MA.

Watts, D., \& Widdowson, B. (2000). Beyond hierarchies: Networks \& organizational performance. In Embracing complexity: A Summary of 1999 Colloquium on the Application of Complex Adaptive Systems to Business (pp. 37-48). Cambridge, MA: Ernst \& Young.

Yamakage, S. (2007). Jinkō shakai kōchiku shinan: Artisoc ni yoru maruchiējento shimyurēshon nyūmon [Artificial society building instruction: Introduction to multi-agent simulation with artisoc]. Tokyo, Japan: Shoseki Kobo Hayayama and Tosho Shimbun. Yamakage, S., \& Hattori, S. (Eds.) (2002). Konpyūta no naka no jinkō shakai: Maruchiējento shimyurēshon moderu to fukuzatsu-kei [Artificial society in computers: Multi-agent simulation model and complexity]. Tokyo, Japan: Kozo Keikaku Engineering and Kyoritsu Shuppan. 